CZASOPISMO INŻYNIERII LĄDOWEJ, ŚRODOWISKA I ARCHITEKTURY JOURNAL OF CIVIL ENGINEERING, ENVIRONMENT AND ARCHITECTURE

JCEEA, t. XXXIV, z. 64 (1/17), styczeń-marzec 2017, s. 449-460, DOI:10.7862/rb.2017.41

\author{
Grzegorz PIĄTKOWSKI \\ Barbara MARKIEWICZ ${ }^{2}$ \\ Karol PERETA ${ }^{3}$
}

\title{
MEASURED AND CALCULATED DYNAMIC PROPERTIES OF THE BRIDGE DECK MODEL REINFORCED WITH FRP BARS
}

\begin{abstract}
Composite materials mainly used in the aeronautics industry are gaining more and more application in various areas such as the construction of bridges. The article presents a set of dynamic researches carried out on a plate made of lightweight concrete reinforced with composite bars. The tested plate with dimensions $514 \times 190 \times 18 \mathrm{~cm}$ was a model of the real bridge deck.

A multi-channel signal recorder with specialized software was used for performing the measurements and to estimate modal parameters of the plate. Dynamic response of the plate on a modal hammer impact was measured with numerous of piezoelectric acceleration sensors. The vibration tests were carried out simultaneously with statics tests only for non-cracked concrete of the plate.

A range of FEM models was created, started with analytical 1-D beam model. Next, more complex 2-D plate and 3-D volume models were developed. The aim was to show how the results change in terms of complexity of the model. Only in the 3-D model the composite rebar was modelled. Additionally, in case of 2-D and 3 -D models there were considered various lengths of the selected support.

The basic frequencies and mode shapes obtained for physical model were compared with those for numerical models. There were significant differences. The conducted analysis indicated more complicated than theoretical boundary conditions of the tested plate.
\end{abstract}

Keywords: lightweight concrete, composite reinforcement bars, classical modal analysis, FEM modelling

1 Corresponding author/autor do korespondencji: Grzegorz Piątkowski, Rzeszow University of Technology, Faculty of Civil and Environmental Engineering and Architecture, al. Powstańców Warszawy 6, 35-959 Rzeszów, phone: +48 178651494, grzegorz.piatkowski@prz.edu.pl

2 Barbara Markiewicz, Rzeszow University of Technology, Faculty of Civil and Environmental Engineering and Architecture, al. Powstańców Warszawy 6, 35-959 Rzeszów, phone: +48 178651619, bmarkiewicz@ prz.edu.pl

3 Karol Pereta, Rzeszow University of Technology, Faculty of Civil and Environmental Engineering and Architecture, al. Powstańców Warszawy 6, 35-959 Rzeszów, phone: +48 178651618, kpereta@prz.edu.pl 


\section{Introduction}

Composites which are relatively new in civil engineering have been used for many years in the aircraft industry. The availability and low price are the biggest advantages of traditional materials in comparison to the price of those new ones, like mentioned Fiberglass Reinforced Plastic composites. However, competitive advantages of FRP composites are low weight, high strength and total corrosion resistance, which mean low maintenance costs. Because of the fact that the exploitation is more expensive, composites are cost-effective compared to conventional materials.

FRP composites have been widely used in bridge structures to strengthen the existing bridges since 1997 [1]. However, still no bridge or overpass has been built with the use of reinforcement bars or composite carrying elements.

The research conducted by consortium Mostostal Warszawa SA and Rzeszów University of Technology has been the first attempt to change the existing situation [2]. This paper presents the research which has been a part of the so-called "Combridge" project. This project is financed by The National Centre for Research and Development in Demonstrator+ program. The aim of this program is to build the first Polish bridge made of FRP composites [3].

\section{Description of the tested plate}

A double span plate has been studied. A theoretical length of each span has been equal to $240 \mathrm{~cm}$. The discussed plate has been a model of a real bridge deck made of a FRP grid-reinforced concrete LC35/38. The averaged density of LC $35 / 38$ concrete has been equal $1970 \mathrm{~kg} / \mathrm{m}^{3}$ and has been determined on the basis of investigation for eight specimens taken during concreting.

The FRP reinforcement bars of $12 \mathrm{~mm}$ diameter have been used in two grids with $8 \mathrm{~cm}$ spacing, lower and upper in distance of $12 \mathrm{~cm}$.

Static scheme and model dimensions have been presented in Fig.1.
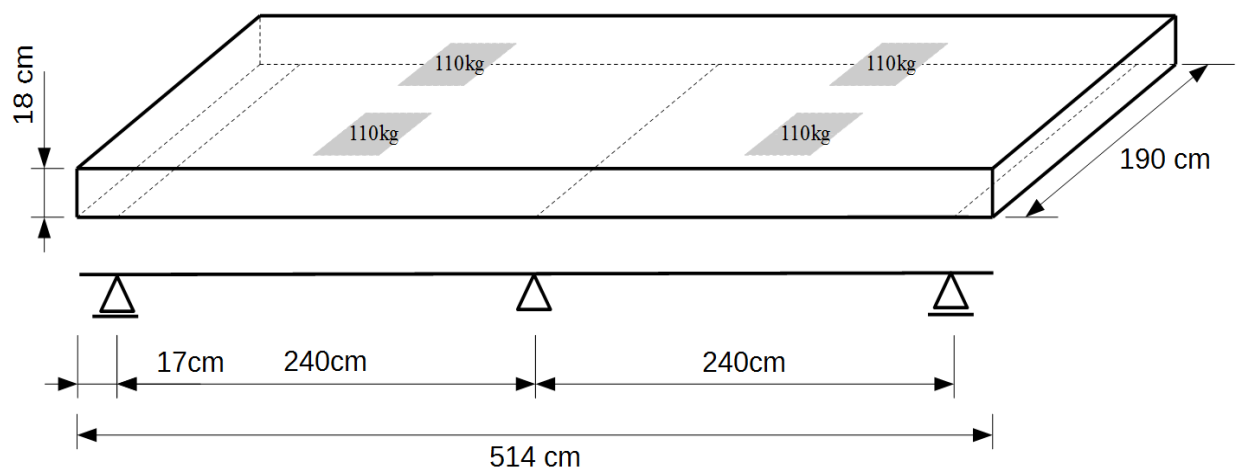

Rys. 1. Schemat statyczny i wymiary płyty

Fig. 1. Static scheme and dimensions of the plate 
The plate has been pinned in the centre and supported in the sliding manner near the edges. Support has been implemented in the form of cylindrical roller bearings and steel panels. Plate has been attached to steel panels by means of cement mortar. Theoretical length of each support has been equal to $190 \mathrm{~cm}$ which is the total width of the plate.

Steel profiles and rubber spacers have been used to transmit the load generated by the actuators of the research station on the deck. The load has been transferred to four areas whose dimensions have been equal $40 \mathrm{~cm}$ x $40 \mathrm{~cm}$. The total additional mass has been equal to $440 \mathrm{~kg}$, Fig.1.

\section{Measurements}

As a result of the measurements frequencies, vibration modes and damping coefficients have been determined.

The classical modal analysis has been used, which is based on the measurement of the existing force and accelerations at different points of the structure as a response to this force. Impulse excitation in the research has been induced by a modal hammer.

The studies have been conducted in several steps, what has been motivated by parallel static research. The first two stages of the survey have been as follows:

Stage 1. non-cracked state, mass of a plate,

Stage 2. non-cracked state, mass of a plate + additional mass.

Pulse excitation has been generated with PCB Piezotronics modal hammer weighing $1.1 \mathrm{~kg}$ and with a sensitivity of $0.23 \mathrm{mV} / \mathrm{N}$. Soft tip has been used. Pulse excitation has been generated in four points shown in Fig. 2 in the vertical direction.

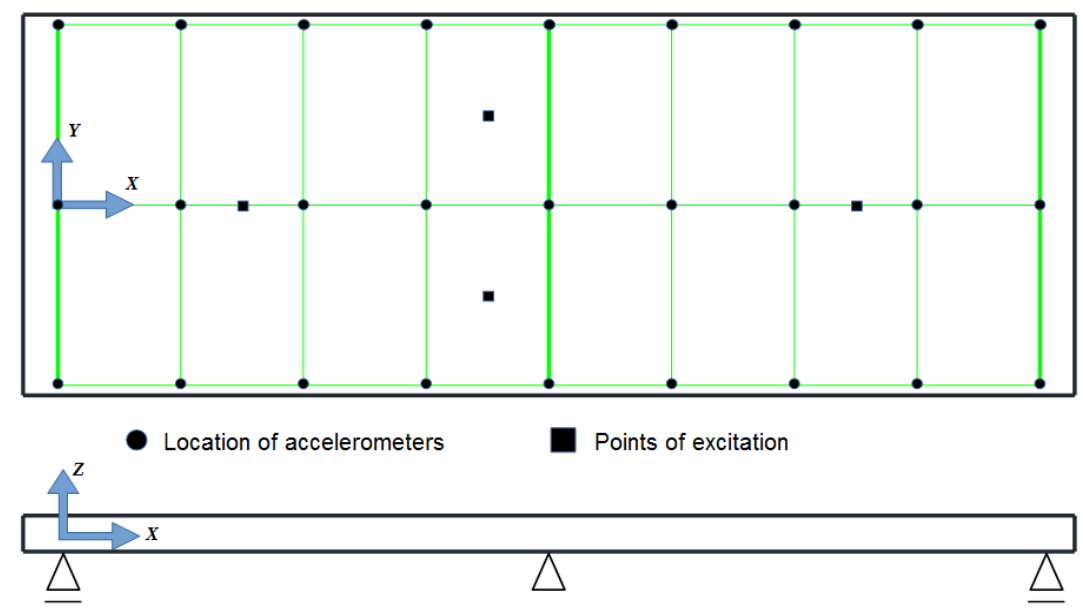

Rys. 2. Położenie punktów pomiarowych

Fig. 2. Location of measurement points 
Dynamic response of the plate has been measured by piezoelectric accelerometers. The vertical accelerations have been measured by 27 accelerometer sensors. All the measurement points have been located on the upper surface of the plate, what is shown in Fig. 2. The placement of measurement points has corresponded to support scheme of the plate. Sensor offset from the longer edges of the plate has been $5 \mathrm{~cm}$ and from the shorter ones $17 \mathrm{~cm}$. As a result, measurement mesh of a total size $480 \mathrm{~cm} \times 180 \mathrm{~cm}$ has been received.

Multi-channel signal recorder Scadas Mobile's LMS International has been used in measurements. Signals in the frequency range $0-256 \mathrm{~Hz}$ with a resolution of $0.125 \mathrm{~Hz}$ have been recorded during acceleration measurements. Recorder software allows for the classical experimental modal analysis including estimation of poles using Polymax method and visualization of the results.

\section{Modal test results}

The vibration of the plate has been measured in stages 1 and 2. In stage 2. the additional mass of metal and rubber spacers located on the plate has been included.

Dynamic characteristics which are the results of modal analysis for stage 1 have been shown in Table 1. Mode shapes for the first two modes have been presented in Fig. 3 and Fig. 4. The range of the values of the first (f1) and second frequencies (f2) have been presented in the min-max variability because excitation for modal analysis has been made in different points.

Tabela 1. Wyniki analizy modalnej - stan 1

Table 1. Modal analysis results - stage 1

\begin{tabular}{|c|c|c|c|c|}
\cline { 2 - 5 } \multicolumn{1}{c|}{} & $\begin{array}{c}\text { Minimum frequency } \\
{[\mathbf{H z}]}\end{array}$ & $\begin{array}{c}\text { Maximum frequency } \\
{[\mathbf{H z}]}\end{array}$ & $\begin{array}{c}\text { Minimum } \\
\text { damping coefficient } \\
{[\%]}\end{array}$ & $\begin{array}{c}\text { Maximum } \\
\text { damping coefficient } \\
{[\%]}\end{array}$ \\
\hline f1 & 36,43 & 36,66 & 1,05 & 1,16 \\
\hline f2 & 50,36 & 50,57 & 1,47 & 1,76 \\
\hline
\end{tabular}

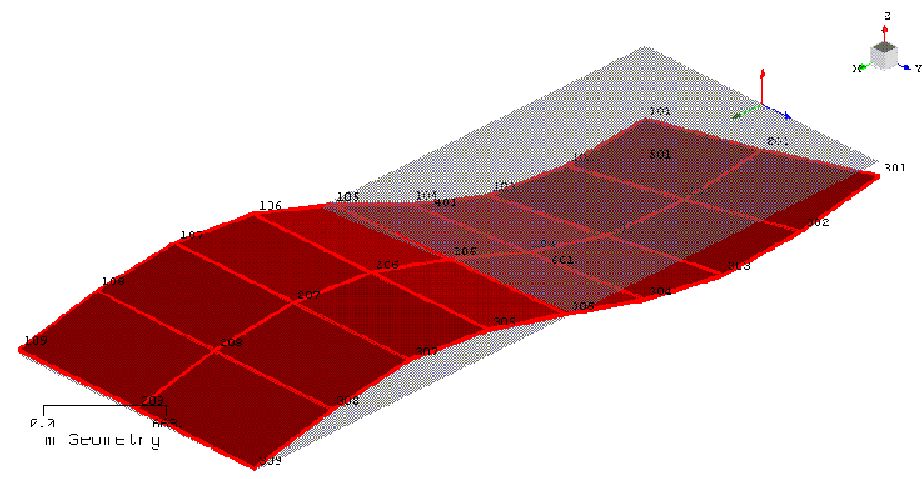

Rys. 3. Pierwsza postać - stan 1

Fig. 3. First mode shape - stage 1 


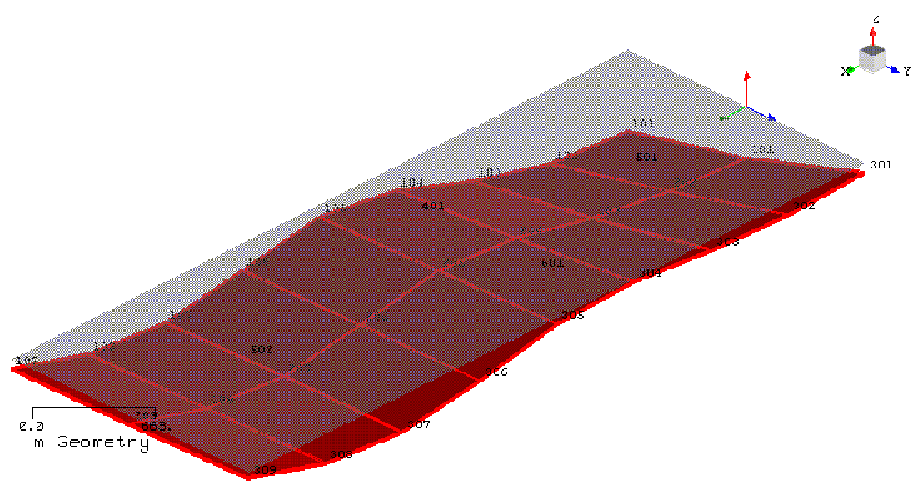

Rys. 4. Druga postać - stan 1

Fig. 4. Second mode shape - stage 1

Dynamic characteristics which are the results of modal analysis for stage 2 have been shown in Table 2. As expected, additional mass resulted in decreasing of the frequencies and increasing of damping coefficient values. As in stage 1. the mode shape of the plate has suggested problem with one of the supports.

Tabela 2. Wyniki analizy modalnej - stan 2

Table 2. Modal analysis results - stage 2

\begin{tabular}{|c|c|c|c|c|}
\cline { 2 - 5 } \multicolumn{1}{c|}{} & $\begin{array}{c}\text { Minimum frequency } \\
{[\mathbf{H z}]}\end{array}$ & $\begin{array}{c}\text { Maximum frequency } \\
{[\mathbf{H z}]}\end{array}$ & $\begin{array}{c}\text { Minimum } \\
\text { damping coefficient } \\
{[\%]}\end{array}$ & $\begin{array}{c}\text { Maximum } \\
\text { damping coefficient } \\
{[\%]}\end{array}$ \\
\hline f1 & 35,70 & 35,85 & 1,92 & 2,26 \\
\hline f2 & 45,49 & 45,65 & 3,09 & 3,73 \\
\hline
\end{tabular}

\section{Analytical model}

Even in case of complex structures preliminary estimates of the dynamic properties can be based on the simplest numerical model. The first model of a studied plate has been a two-spanned beam, for which two first frequencies have been calculated using closed formulas. The formulas (1) and (2) have been determined for half schemes of symmetric beam and appropriate boundary conditions. The first mode shape has been shown in Fig. 5 and frequency for this mode has been described by formula (1).

$$
f_{1}=\frac{k^{2} \cdot \pi^{2}}{l^{2}} \cdot \sqrt{\frac{E I}{\mu}}
$$

where: $l$-span length; $\mu$ - linear density;

$E I$ - stiffness; $k$-number of particular type of mode. 


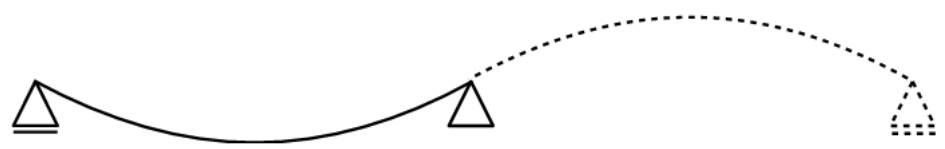

Rys. 5. Antysymetryczna funkcja kształtu dla k=1

Fig. 5. Antisymmetric eigen mode shape of a beam for $\mathrm{k}=1$

The second mode shape has been shown in Fig. 6 and frequency for this mode has been described by formula (2).

$$
f_{2}=\left(\frac{4 k+1}{4}\right)^{2} \cdot \frac{\pi^{2}}{l^{2}} \cdot \sqrt{\frac{E I}{\mu}}
$$

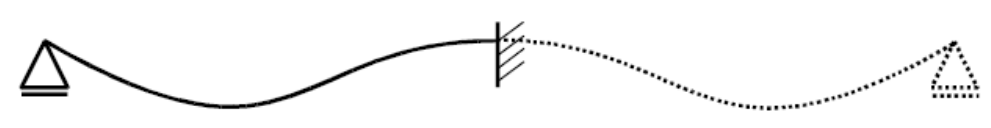

Rys. 6. Symetryczna funkcja kształtu dla $\mathrm{k}=1$

Fig. 6. Symmetric eigen mode shape of a beam for $\mathrm{k}=1$

The data to be taken for the calculations: the Young's modulus of LC35/38 concrete equal to 21,5 GPa (according to EC 2), moment of inertia $92340 \mathrm{~cm}^{4}$ and linear density $673,74 \mathrm{~kg} / \mathrm{m}$. The linear density has been calculated on the basis of the value $1970 \mathrm{~kg} / \mathrm{m}^{3}$. The length of each span has been equal to $2,4 \mathrm{~m}$. The reinforcement and cantilevers have been omitted.

For stage 2. the total mass of additional elements located on the deck has been converted to additional density. Therefore the value of linear density has been increased to $765,41 \mathrm{~kg} / \mathrm{m}$.

\section{Numerical models}

\subsection{FEM 1-D and 2-D models}

The ADINA program has been used for building of numerical models.

The Young's modulus in numerical models has been the same as in analytical model and volume density has been equal to $1970 \mathrm{~kg} / \mathrm{m}^{3}$, which is also corresponding with the above mentioned data.

Two numerical BEAM [2] models have been created to compare obtained frequencies with analytical results. 
Tabela 3. Częstotliwości dwóch pierwszych postaci drgań własnych dla modelu 1-D

Table 3. Frequencies of two first mode shapes for 1-D model

\begin{tabular}{|c|c|c|c|c|}
\hline \multirow{2}{*}{$\begin{array}{c}\text { Frequencies } \\
\text { [Hz] }\end{array}$} & \multicolumn{2}{|c|}{ Analytical calculations } & \multicolumn{2}{c|}{ ADINA } \\
\cline { 2 - 5 } & $\begin{array}{c}\text { Without } \\
\text { additional mass }\end{array}$ & $\begin{array}{c}\text { With additional } \\
\text { mass }\end{array}$ & $\begin{array}{c}\text { Without } \\
\text { additional mass }\end{array}$ & $\begin{array}{c}\text { With additional } \\
\text { mass }\end{array}$ \\
\hline f1 & 46,88 & 43,98 & 46,70 & 41,82 \\
\hline $\mathbf{f 2}$ & 73,25 & 68,72 & 72,86 & 66,15 \\
\hline
\end{tabular}

The cantilevers have been considered in all numerical models. In the first model only the mass of the plate has been included. In the second model additional mass has been included The results have been shown in Table 3 .

Received in the ADINA results differ from those obtained analytically by less than $0.5 \%$ in the case without the additional mass. The difference is due to the fact that the analytical calculation does not include overhangs. Consideration of additional masses on appropriate sections of the beam reduces the numerically calculated vibration frequency compared to the frequency obtained with the analytical model of an average weight of the whole span length, but the difference in frequency values is less than $5 \%$.

Comparing these results with the results of the measurements given in 1 and 2 , the calculated frequencies seem to be too high. The analytical model and numerical model 1-D are limited in terms of defining the actual conditions of the support of the plate. It is impossible therefore to consider the lack of contact between the plate and the support.

Tabela 4. Częstotliwości dwóch pierwszych postaci drgań własnych dla modelu 2-D

Table 4. Frequencies of two first mode shapes for 2-D model

\begin{tabular}{|c|c|c|c|c|}
\hline \multirow{2}{*}{$\begin{array}{c}\text { Frequencies } \\
{[\mathbf{H z}]}\end{array}$} & \multicolumn{4}{|c|}{ Ratio of length of the support to width of the plate [-] } \\
\cline { 2 - 5 } & $\mathbf{1 / 1}$ & $\mathbf{1 / 2}$ & $\mathbf{1 / 4}$ & $\mathbf{1 / 8}$ \\
\hline $\mathbf{f 1}$ & 41,84 & 40,82 & 36,45 & 36,33 \\
\hline $\mathbf{f} \mathbf{2}$ & 65,76 & 62,37 & 51,92 & 51,72 \\
\hline
\end{tabular}

In order to consider deviation from the theoretical support the 2-D model has been created. It has been formed with the use of eight-node type SHELL elements [4]. The plate has been analysed as non-cracked, and the stiffness of reinforcement has been omitted. The additional masses have been modelled as change in the material density for selected areas (Fig. 7). The boundary conditions have been defined for nodes on selected lines (Fig. 7).

Four models in which the ratio of the length of the left support to width of the plate has been as follows: 1,1/2,1/4, 1/8, have been investigated in order to test the effect of these boundary conditions on the basic frequencies (Table 4). In Fig. 7 the model with the ratio 1/1 of the left support has been shown. 


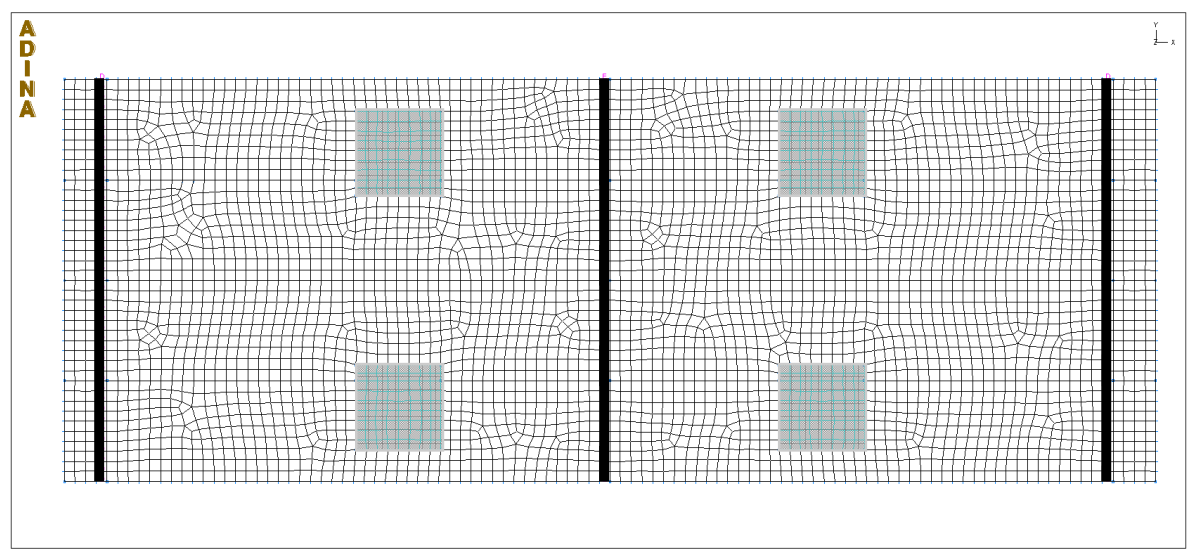

Rys. 7. Model 2-D badanej płyty

Fig. 7. 2-D model of the studied plate

\subsection{FEM 3-D model}

The 3-D model of the plate has been made of eight-node SOLID elements [4]. The basic assumptions for this model have been the same as in case of 2-D model.

The composite reinforcement has been included with the use of two-node TRUSS element [2]. The Young's modulus of these composite reinforcement bars has been equal to $57,8 \mathrm{GPa}$ (technical data derived from manufacturer).

Solid model has been made for the same support options as the 2-D model. The results have been listed in Table 5 .

Tabela 5. Częstotliwości dwóch pierwszych postaci drgań własnych dla modelu 3-D

Table 5. Frequencies of two first mode shapes for 3-D model

\begin{tabular}{|c|c|c|c|c|c|}
\hline \multirow{3}{*}{$\begin{array}{c}\text { Frequencies } \\
{[\mathrm{Hz}]}\end{array}$} & \multicolumn{5}{|c|}{ Ratio of length of the support to width of the plate [-] } \\
\hline & \multirow{2}{*}{$\begin{array}{c}\begin{array}{c}\text { Without } \\
\text { reinforcement }\end{array} \\
1 / 1 \\
\end{array}$} & \multicolumn{4}{|c|}{ With reinforcement } \\
\hline & & $1 / 1$ & $1 / 2$ & $1 / 4$ & $1 / 8$ \\
\hline f1 & 41,31 & 42,40 & 41,33 & 36,67 & 36,04 \\
\hline f2 & 65,73 & 67,38 & 63,76 & 52,69 & 52,49 \\
\hline
\end{tabular}

The mode shapes of 3-D model have been shown in Fig. 9. They have been similar to these obtained for 1-D and 2-D models. 


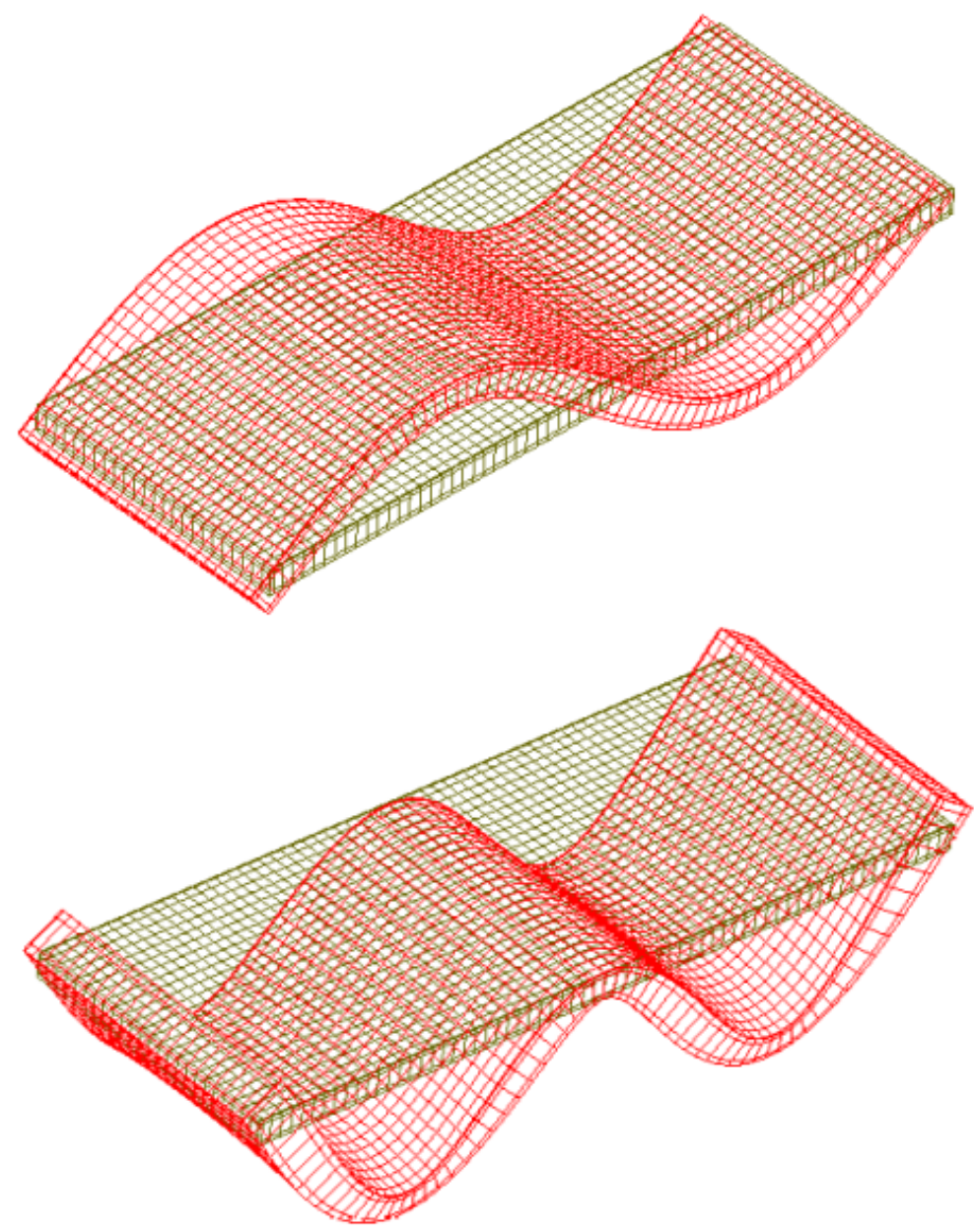

Rys. 8. Dwie pierwsze postacie drgań własnych dla modelu 3-D, dla stosunku długości podparcia $1 / 1$

Fig. 8. Two first mode shapes of 3-D model for support with ratio 1/1

The frequency of the plate has increased of $2-3 \%$ by included reinforcement. The frequency has decreased in case of reducing the length of the contact between the plate and one of the support of the edges. The difference between the results for the total supporting and supporting $1 / 8$ of the width reaches $34 \%$. 


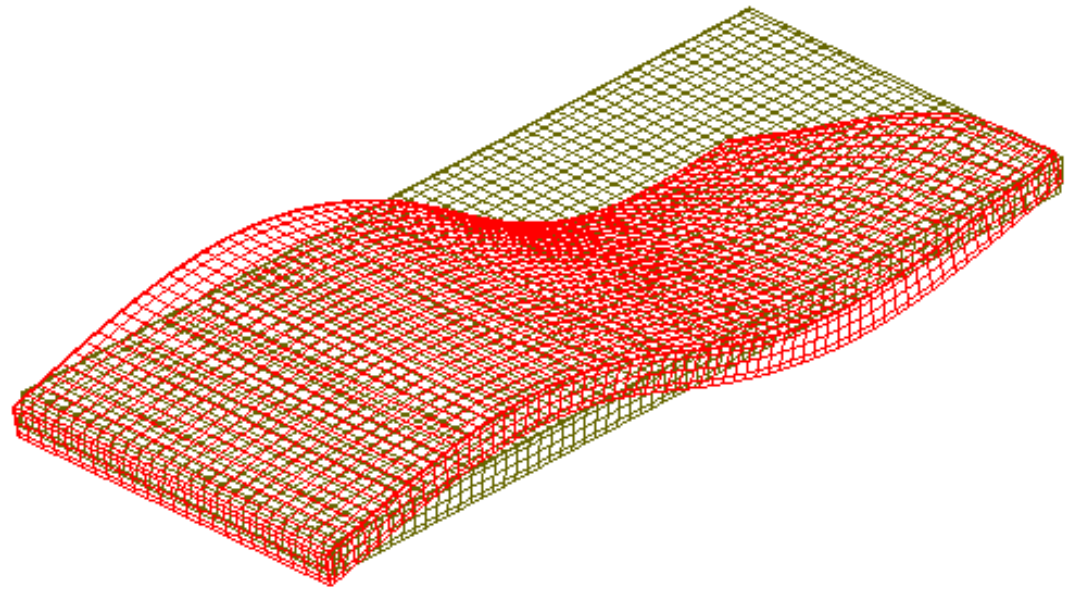

Rys. 9. Pierwsza postać drgań własnych dla modelu 3-D, dla stosunku długości podparcia $1 / 4$

Fig. 9. First mode shape of 3-D model for support with ratio $1 / 4$

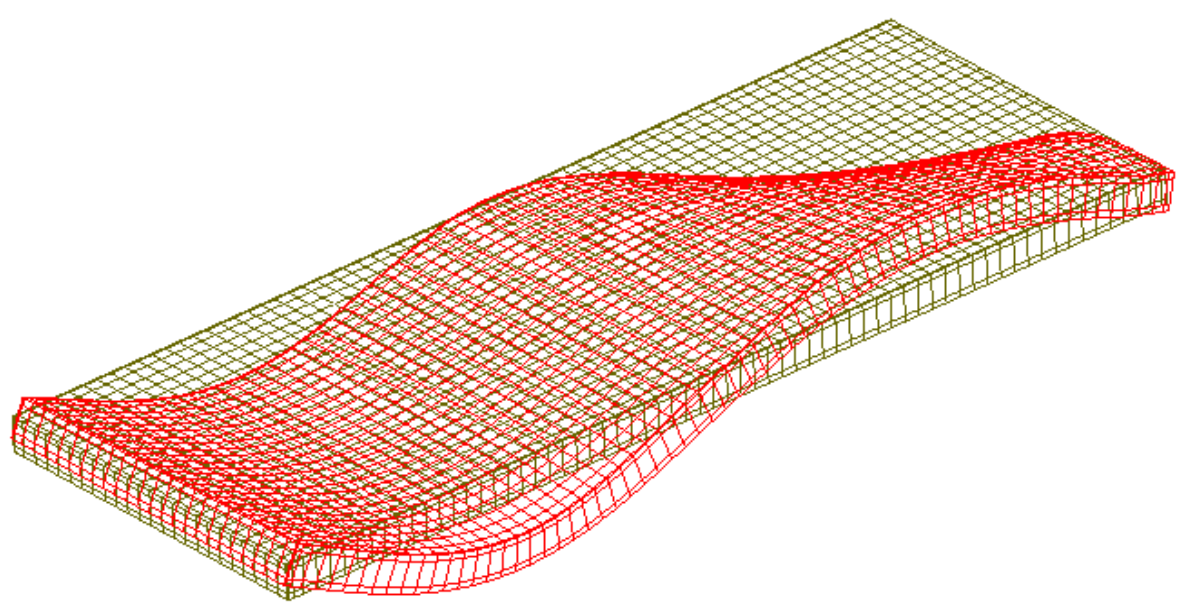

Rys. 10. Druga postać drgań własnych dla modelu 3-D, dla stosunku długości podparcia $1 / 4$

Fig. 10. Second mode shape of 3-D model for support with ratio $1 / 4$ 


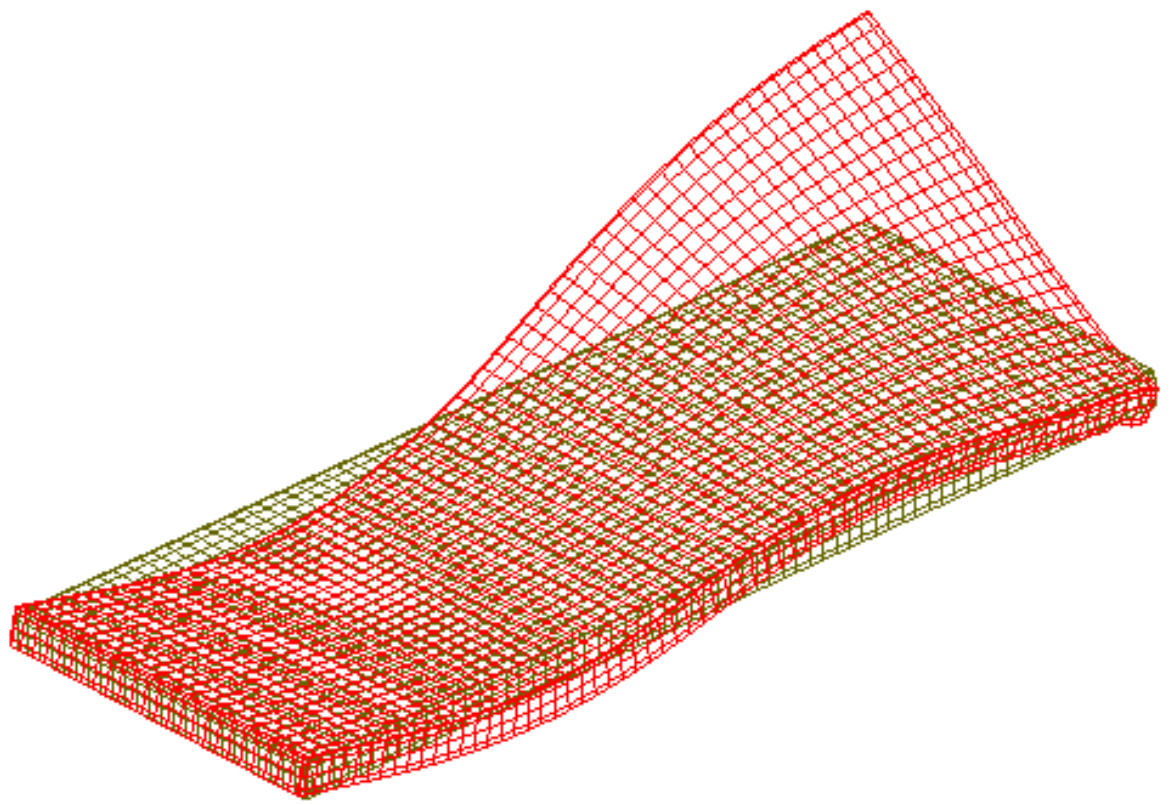

Rys. 11. Druga postać drgań własnych dla modelu 3-D, dla stosunku długości podparcia 1/8

Fig. 11. Second mode shape of 3-D model for support with ratio $1 / 8$

\section{Conclusions}

Interesting is the fact, that the results calculated using closed formulas for simplified beam, which takes only few minutes, differ only 5-6\% from fully supported 3-D MES model created in ADINA. This shows that even such simple calculations can be an introduction to the complex study and also can lead to some conclusions already, as lack of the contact on one of the supports.

The most similar to results obtained in research are frequencies calculated for both 2-D and 3-D model as well, with length of support equal to 1/4 width of the plate on one of the edges. The similarities refer not only to values (2\% difference in the frequencies for the first mode, $15 \%$ for the second) but also to mode shapes, which have been presented in Fig. 3 and Fig.10. Determined for numerical model second mode shape for $1 / 8$ width of supporting of the plate has had different nature. It was another antisymmetric mode shape.

The results presented above allow for the additional conclusion that the actual length of supporting has been near $1 / 4$ of the width of the plate. 


\section{Bibliography}

[1] Siwowski T., Radomski W.: Pierwsze krajowe zastosowanie taśm kompozytowych do wzmocnienia mostu. Inżynieria i Budownictwo, rok LIV, nr 7, 1998, s. 382-388.

[2] Siwowski T., Kulpa M., Poneta P., Badania nad zastosowaniem kompozytów FRP do budowy mostów w Polsce. Materiały Budowlane, Nr 11, 2014, s. 58-60.

[3] Siwowski T., Kaleta D., Kulpa M., Poneta P., Pierwszy polski most kompozytowy koncepcja techniczna i badania wstępne. Polskie Drogi, nr 6(216)/2014, s. 84-89.

[4] Bathe K. J. Finite Element Procedures, Prentice Hall, 1996.

\section{ZBADANE I OBLICZONE WŁAŚCIWOŚCI DYNAMICZNE PŁYTY POMOSTOWEJ ZBROJONEJ PRĘTAMI KOMPOZYTOWYMI}

\section{Streszczenie}

Materiały kompozytowe, używane głównie w przemyśle lotniczym, coraz częściej wykorzystywane są również w konstrukcjach mostowych. W niniejszym artykule przedstawiono badania dynamiczne płyty pomostu wykonanej $\mathrm{z}$ betonu lekkiego zbrojonego prętami kompozytowymi oraz ciąg modeli MES mających na celu odwzorowanie modelu laboratoryjnego płyty. Płyta poddana badaniom miała wymiary 514 x $190 \times 18 \mathrm{~cm}$.

Odpowiedź dynamiczną płyty mierzono piezoelektrycznymi czujnikami przyspieszeń. Zastosowano 27 jednoosiowych czujników przyspieszeń, co pozwoliło na rejestrowanie przyspieszenia drgań w kierunku pionowym $Z$ wzbudzanych młotkiem modalnym. Do pomiarów wykorzystano wielokanałowy rejestrator sygnałów. Oprogramowanie rejestratora zapewnia prowadzenie eksperymentalnej klasycznej analizy modalnej włącznie z estymacją biegunów metodą PolyMAX oraz wizualizację uzyskanych wyników.

W celu odwzorowania zachowania modelu laboratoryjnego wykonano szereg modeli obliczeniowych. Zaczynając od uproszczonego modelu analitycznego 1-D, następnie poprzez modele numeryczne metody elementów skończonych 1-D, 2-D i 3-D wykonane w programie ADINA, ukazano jak zmieniają się wyniki w zależności od złożoności modelu. W modelach 2-D i 3-D uwzględniono możliwość niepełnego podparcia płyty na jednej ze skrajnych podpór, co sugerowały wyniki otrzymane na drodze badań. Obecność zbrojenia została uwzględniona jedynie w modelu 3-D.

Obliczone podstawowe częstotliwości drgań własnych oraz odpowiadające im formy drgań porównano $\mathrm{z}$ częstotliwościami i formami otrzymanymi podczas badań laboratoryjnych. Stwierdzone różnice $\mathrm{w}$ formach drgań wskazywały na odbiegający od założonego sposób podparcia płyty.

Słowa kluczowe: płyta pomostu, pręty FRP, beton lekki, analiza modalna, modelowanie MES

Przestano do redakcji: 30.11 .2016 r.

Przyjęto do druku: 31.03.2017 r. 